\title{
Revisiting the Role of p53 in Prostate Cancer
}

\author{
Miriam Teroerde ${ }^{1} \bullet$ Cathleen Nientiedt ${ }^{2} \bullet$ Anette Duensing 3,4,5,6 • \\ Markus Hohenfellner ${ }^{3} \bullet$ Albrecht Stenzinger $^{7} \bullet$ Stefan Duensing ${ }^{1,3}$ \\ ${ }^{1}$ Molecular Urooncology, Department of Urology, University Hospital Heidelberg, \\ Im Neuenheimer Feld 517, D-69120 Heidelberg, Germany; ${ }^{2}$ Department of Medical \\ Oncology, University Hospital Heidelberg and National Center for Tumor Diseases \\ (NCT), Im Neuenheimer Feld 460, D-69120 Heidelberg, Germany; ${ }^{3}$ Department of \\ Urology, University Hospital Heidelberg and National Center for Tumor Diseases \\ (NCT) Heidelberg, Im Neuenheimer Feld 420, D-69120 Heidelberg Germany; \\ ${ }^{4}$ Precision Oncology of Urological Malignancies, Department of Urology, University \\ Hospital Heidelberg, Im Neuenheimer Feld 517, D-69120 Heidelberg, Germany; \\ ${ }^{5}$ Cancer Therapeutics Program, University of Pittsburgh School of Medicine, UPMC \\ Hillman Cancer Center, 5117 Centre Avenue, Pittsburgh, PA 15213, USA; ${ }^{6}$ Department of \\ Pathology, University of Pittsburgh School of Medicine, 200 Lothrop Street, Pittsburgh, \\ Pittsburgh, PA 15261, USA; ${ }^{7}$ Institute of Pathology, University Hospital Heidelberg, \\ Im Neuenheimer Feld 224, D-69120, Heidelberg, Germany
}

Author for correspondence: Stefan Duensing, Molecular Urooncology, Department of Urology, University Hospital Heidelberg, Im Neuenheimer Feld 517, D-69120 Heidelberg, Germany. E-mail: stefan.duensing@med.uni-heidelberg.de

Doi: https://doi.org/10.36255/exonpublications.prostatecancer.p53.2021

\begin{abstract}
Mutations in the tumor suppressor gene TP53 are among the most common genetic aberrations in cancer. In prostate cancer, the role of mutant TP53 remains incompletely understood. Initially, mutations in TP53 were considered late events during malignant progression and associated with metastatic dissemination and castration resistance. However, recent studies report an inactivation of TP53 at an unexpectedly high frequency in primary as well as metastatic castration-naive prostate cancer. In this chapter, we discuss the biology of p53, the relevance of TP53 mutations for prostate cancer progression and therapy
\end{abstract}

In: Prostate Cancer. Bott SRJ, Ng KL (Editors). Exon Publications, Brisbane, Australia. ISBN: 978-0-6450017-5-4; Doi: https://doi.org/10.36255/exonpublications.prostatecancer.2021

Copyright: The Authors.

License: This open access article is licenced under Creative Commons Attribution-NonCommercial 4.0 International (CC BY-NC 4.0) https://creativecommons.org/licenses/by-nc/4.0/ 
resistance, and its potential role as a marker to identify patients who require more intensified treatment.

Keywords: castration-naïve prostate cancer; castration-resistant prostate cancer; p53, therapy resistance; TP53

\section{INTRODUCTION}

Prostate cancer is the most common non-cutaneous cancer in men (1). Due to the introduction of broader screening and testing for prostate-specific antigen (PSA) blood levels, the majority of prostate cancers are now diagnosed at a localized state (2). Prostate cancer is a heterogeneous disease, and the clinical outcome of localized prostate cancer is highly variable. Approximately $30 \%$ of men suffer from relapse despite definitive local treatment by radical prostatectomy or percutaneous radiotherapy (3). Localized prostate carcinoma already shows a substantial molecular and genetic diversity (4). There is hence an urgent clinical need to identify molecular and genetic markers with predictive and prognostic relevance in addition to "classical" outcome parameters such as TNM stage, Gleason score and initial PSA level (5). A better characterization of genetic factors associated with more aggressive tumor growth kinetics could influence clinical decision-making with respect to more personalized neoadjuvant and/or adjuvant strategies (6).

The finding that a significant proportion of men with advanced prostate cancer harbor germline and/or somatic mutations in DNA damage repair genes has been a major advancement in the management of the disease (7). It has been known for a while that tumors with DNA damage repair gene defects are associated with earlier metastatic dissemination and poorer disease outcome (8-11). At the same time, mutations, in particular in BRCA1 and BRCA2, create a therapeutic vulnerability that has been exploited by the use of PARP inhibitors in patients with metastatic, castration-resistant prostate cancer (mCRPC) $(11,12)$. Recent results from several phase II and III trials confirm a clinical advantage of PARP inhibition in terms of progression-free and overall survival (12-18). However, there is mounting evidence that not all patients who are broadly categorized as carrying DNA damage repair gene defects (in fact many of these genes play only indirect roles in DNA damage repair) benefit from PARP inhibition (19). Therefore, additional molecular markers are needed to characterize therapeutic vulnerabilities, treatment resistance and patient prognosis with an even higher resolution.

A gene that is typically not included in targeted next-generation sequencing (NGS) panels used in key phase II and III trials to identify patients for PARP inhibitor treatment is TP53, one of the most frequently altered tumor suppressor genes in human cancer.

\section{THE EVOLUTION AND FUNCTION OF p53}

p53 was first discovered in 1979 and initially thought to be an oncogene (20-24). Subsequent work demonstrated that the transcription factor p53, together with 
its E3 ubiquitin ligase MDM2, is at the center of a signaling node that plays a crucial role in stress response and tissue homeostasis (25). Over hundreds of millions of years, the p53 family has evolved from protecting the germline of invertebrates from mutations to a more general signaling hub that preserves the tissue integrity of vertebrates (25). p53 responds to a diverse array of cellular stresses by activating the transcription of genes that either lead to a reconstitution of the damaged cell or its elimination by apoptosis or cellular senescence (26). p53-dependent transcription hence promotes cell cycle arrest, DNA repair, metabolic adaptation, or the upregulation of pro-apoptotic genes such as BAX or PUMA or pro-senescence genes such as PML or CDKN1A. These properties as key regulator of cell fate decision make p53 the single most critical human tumor suppressor and contribute to the fact that TP53 is the most commonly altered gene in human cancer $(27,28)$.

Physiologically, p53 is expressed at a low level in most normal cells, which involves a number of cellular antagonists, most importantly its E3 ubiquitin ligase MDM2 and its heterodimerization partner, MDM4 (29). By ubiquitinating p53, MDM2 drives the proteasomal degradation of p53 (30). MDM2 itself is positively regulated by p53 thus creating a feedback loop to ensure low p53 protein levels in the absence of cellular stress. Over a dozen of extrinsic and intrinsic stress signals have been reported to feed into the MDM2-p53 signaling node to cause activation of p53-dependent gene transcription (25). The p53 response is activated by decreased degradation upon disruption of the p53/MDM2/MDM4 complex leading to p53 stabilization. The disruption of these interactions is regulated by posttranslational modifications of MDM2 and/or p53 such as phosphorylation by protein kinases activated by stress such as ATR, ATM, CHK1, CHK2 or DNA-PK, among others $(25,31)$. Additional mechanisms of p53 activation exist such as the nucleolar sequestration of MDM2 by ARF in response to oncogene stress (32). Another mechanism of activation of the MDM2-p53 node involves the deubiquitinating enzyme HAUSP (33). Obviously, different sources of cellular stress can trigger distinct modes of p53 activation depending on the responding protein kinases.

Upon its activation, p53 binds to the promoter of p53-responsive target genes to activate gene transcription. MDM2 and MDM4 are co-recruited to these promoters where they form a complex with p53 to modulate target gene activation (34).

\section{STRUCTURE OF p53}

The tumor suppressor gene TP53 encodes a protein with 393 amino acids and is located on chromosome $17 \mathrm{p} 13.1$ (35). The p53 protein comprises an N-terminal transactivation domain, a proline-rich domain, a central DNA-binding domain, followed by a tetramerization domain and an intrinsically disordered C-terminal regulatory domain (36). Inactivating mutations in TP53 occur in approximately $50 \%$ of human cancers, and mutation rates range between more than $90 \%$ and below 5\% depending on the tumor type (37). Most mutations are detected in the central DNA-binding domain, thereby incapacitating the function of p53 as a transcription factor. Missense mutations, frameshift deletions and frameshift 
insertions account for approximately $70 \%$ of pathogenic mutations (37). Inactivation of both TP53 alleles is found in over 90\% of cancers with TP53 mutations, most commonly through a single missense mutation and loss of the second allele through a deletion of chromosome 17p (37). Missense mutations frequently lead to an impaired degradation by MDM2 thus stabilizing the protein and rendering it easily detectable as overexpressed by immunohistochemistry (38). Remarkably, the top hotspot missense mutations occur at methylated CpG sites, which encode evolutionary conserved arginine residues. The most common mutation is R175H, followed by R248Q, R273H, R248W, R273C, and R282W, which account for approximately a quarter of all TP53 missense mutations (39). As a functional consequence of these mutations, the transcriptional activation of p53-specific target genes is disrupted $(40,41)$ although gain-of-function mutations have also been described (42).

In addition to acquired mutations, germline mutations of TP53 have been identified in patients with Li-Fraumeni syndrome. The Li-Fraumeni syndrome is characterized by sarcomas, breast and adrenal cortex carcinomas, cerebral tumors, and acute leukemias at a young age $(43,44)$. Germline mutations in TP53 are highly penetrant with an up to $100 \%$ cumulative lifetime risk to develop cancer (45).

\section{TP53 MUTATIONS IN PROSTATE CANCER}

Initially, inactivation of TP53 has been suggested to be a late event during prostate cancer progression (46-49). While it is now firmly established that mCRPC has the highest TP53 mutations rates (see below), there is emerging evidence that TP53 mutations can also be found at a relatively high frequency in primary, and, especially, in castration-naïve metastatic prostate cancer (50-56).

In the TCGA cohort, whole genome sequencing of 333 samples from men with localized prostate cancer was performed and a mutation rate in TP53 of 8\% was detected (51). In a different study, sequencing of 111 cases of primary prostate cancer revealed a TP53 mutation rate of 6\% (57).

Remarkably, the rate of TP53 mutations in castration-naive metastatic prostate cancer was between $28 \%$ and $36 \%$ and hence significantly higher than in primary prostate cancer $(50,52,58)$ and only exceeded by mutation rates found in mCRPC. Analysis of 150 mCRPC samples showed a TP53 mutation rate of $53 \%$ (59). In additional studies, the TP53 mutation rate was between $31 \%$ and 73\% (53, 60-63). Whole-exome sequencing data from 410 mCRPCs identified $33 \%$ of tumors with a biallelic loss of TP53 and 32\% with single-copy loss or a pathogenic mutation (62). These findings confirm the marked differences in the TP53 mutation rate in primary, metastatic castration-naïve and castration-resistant prostate cancer.

Important insights into the role of TP53 deficiency in disease progression stem from studies that incorporate patient outcome measurements and longitudinal studies. Hamid and colleagues showed that TP53 alterations increase from localized castration-naïve prostate cancer (20\%) to metastatic castration-naïve prostate cancer (37\%) and mCRPC (73\%) and are associated with an approximately 2 -fold risk for disease recurrence in patients with primary prostate cancer (53). In a recent 
study by Mateo and colleagues, primary prostate cancer specimens from 175 patients who later developed MCRPC were analyzed. Mutations and homozygous loss of TP53 were the most frequently detected aberrations and found in 25\% of the primary tumors (52). In addition, there appears to be an increase of TP53 alterations, besides alterations of the androgen receptor (AR) pathway, when same-patient specimens obtained from the untreated primary tumor and mCRPC were compared (52).

In conclusion, there is emerging evidence for a high rate of TP53 mutations in primary prostate cancer predisposed to a lethal disease outcome as well as prostate cancer with metastatic dissemination at the time of diagnosis.

\section{p53 AND RESISTANCE OF PROSTATE CANCER TO SYSTEMIC THERAPY}

Prostate cancer growth and progression exquisitely depends on androgens, and androgen deprivation still remains the most important treatment modality for patients with recurrent or metastatic disease (64). However, all patients ultimately develop tumor progression and castration resistance (65). The role of TP53 inactivation in response to androgen deprivation therapy has not been studied in detail. Thus far, there appears to be no negative impact of TP53 alterations in the response to first-line antihormonal treatment (52). In the last decade, several novel therapeutic options for patients with mCRPC have been established including the CYP17 inhibitor abiraterone and the androgen receptor antagonist enzalutamide $(66,67)$. Since not all men benefit from these next-generation antiandrogens, there is a clinical need for markers that indicate primary or acquired resistance to aid decision-making. Because mCRPC still critically depends on AR signaling (68), the constitutively active AR splice variant V7 (AR-V7) has been suggested as a crucial, albeit not exclusive, component of the resistance mechanisms to next-generation antiandrogens $(69,70)$. De Laere and colleagues could demonstrate that inactivation of TP53 was associated with significantly shorter progression-free and overall survival of prostate cancer patients treated with abiraterone or enzalutamide (71). The poorest progression free survival was found in patients with a biallelic TP53 inactivation. Of note, TP53 mutations were the only marker independently associated with an unfavorable response to abiraterone and enzalutamide and, remarkably, outperformed genomic AR alterations and expression of AR splice variants (71). How p53 influences resistance to next-generation antiandrogens remains to be clarified. Interestingly, there is evidence to suggest that wild-type p53 may suppress AR activation (72-74).

The microtubule-stabilizing agent docetaxel is the only chemotherapy that has been shown to extend survival in patients with $\operatorname{mCRPC}(75,76)$. The response of prostate cancer cells to docetaxel has been found to be compromised by mutant p53 (77). The clinical utility of TP53 mutation status as a predictive marker for docetaxel treatment hence warrants further investigation.

Whether and to what extend TP53 perturbations affect the response to the PARP inhibitor olaparib, which has recently been approved for patients with mCRPC and BRCA1/2 mutations $(16,18)$, is currently unclear. 


\section{TP53 AND THE CLONAL EVOLUTION OF PROSTATE CANCER}

Since a substantial proportion of primary prostate cancers harbor mutations in TP53, the question arises whether TP53 inactivation may be a driver event for malignant progression. There is mounting evidence that this could be the case. TP53 mutations have been reported as truncal aberrations in considerable proportions of metastatic prostate cancers $(58,78)$. Interestingly, a case study could demonstrate that a mutant TP53 clone originating from a small, well-differentiated focus of primary prostate cancer was apparently the origin of metastatic spread with a 17-year lag period (79). However, TP53 mutations have also been reported to be enriched in metastatic lesions and there are also examples of tumors in which TP53 aberrations can be found exclusively in metastases $(52,80)$.

In conclusion, TP53 mutations seem to be an early event in some prostate cancers while in others an enrichment in metastatic lesions can be found. In the future, increasingly sensitive detection methods such as single-cell sequencing hold the promise to even better define the molecular composition of primary and metastatic prostate cancer with respect to the TP53 mutation status.

\section{DOES p53 HAVE POTENTIAL AS A THERAPEUTIC TARGET AFTER ALL?}

Given the high frequency of TP53 inactivation in prostate cancer and in cancer in general, the question remains how this finding could be translated into a therapeutic vulnerability. p53 is notoriously difficult to target and numerous studies have used approaches such as gene therapy, inhibition of MDM2 or MDM4 interactions, synthetic lethal approaches, and others (81-85). It should not be forgotten that p53 has originally been discovered as a tumor antigen induced by chemical carcinogens (86). Hence, approaches to exploit mutant p53 as immunological target as well as the increased genomic instability of p53-defective cells through immune oncological interventions still appear promising. In this context, an exacerbation of the mutational burden may further enhance the therapeutic vulnerability of p53-deficient cells to promote responses to immune checkpoint inhibitors.

\section{CONCLUSION}

Inactivation of TP53 has initially been described as a late event during malignant progression and associated mainly with mCRPC. There is now compelling evidence that mutated TP53 can also be detected in primary prostate cancer, and, especially, in castration-naïve metastatic prostate cancer. Inactivation of TP53 predicts an unfavorable patient outcome, early metastatic dissemination, and resistance to next-generation antiandrogens. Therefore, TP53 perturbations have a strong potential as a marker to identify patients with a high risk for lethal disease outcome who could benefit from more intensified treatment. 
Conflict of interest: The authors declare no potential conflict of interest with respect to research, authorship and/or publication of this chapter

Copyright and permission statement: The authors confirm that the materials included in this chapter do not violate copyright laws. Where relevant, appropriate permissions have been obtained from the original copyright holder(s), and all original sources have been appropriately acknowledged or referenced.

\section{REFERENCES}

1. Siegel RL, Miller KD, Jemal A. Cancer statistics, 2020. CA Cancer J Clin. 2020;70(1):7-30. https://doi. org/10.3322/caac. 21590

2. Schröder FH, Hugosson J, Roobol MJ, Tammela TL, Ciatto S, Nelen V, et al. Screening and prostatecancer mortality in a randomized European study. N Engl J Med. 2009;360(13):1320-8. https://doi. org/10.1056/NEJMoa0810084

3. Paller CJ, Antonarakis ES. Management of biochemically recurrent prostate cancer after local therapy: evolving standards of care and new directions. Clin Adv Hematol Oncol. 2013;11(1):14-23.

4. Boutros PC, Fraser M, Harding NJ, de Borja R, Trudel D, Lalonde E, et al. Spatial genomic heterogeneity within localized, multifocal prostate cancer. Nat Genet. 2015;47(7):736-45. https://doi. org/10.1038/ng.3315

5. D'Amico AV. Risk-based management of prostate cancer. N Engl J Med. 2011;365(2):169-71. https:// doi.org/10.1056/NEJMe1103829

6. Beltran H, Rubin MA. New strategies in prostate cancer: translating genomics into the clinic. Clin Cancer Res. 2013;19(3):517-23. https://doi.org/10.1158/1078-0432.CCR-12-1452

7. Mateo J, Boysen G, Barbieri CE, Bryant HE, Castro E, Nelson PS, et al. DNA repair in prostate cancer: biology and clinical implications. Eur Urol. 2017;71(3):417-25. https://doi.org/10.1016/j. eururo.2016.08.037

8. Bednarz N, Eltze E, Semjonow A, Rink M, Andreas A, Mulder L, et al. BRCAl loss preexisting in small subpopulations of prostate cancer is associated with advanced disease and metastatic spread to lymph nodes and peripheral blood. Clin Cancer Res. 2010;16(13):3340-8. https://doi.org/10.1158/10780432.CCR-10-0150

9. Castro E, Jugurnauth-Little S, Karlsson Q, Al-Shahrour F, Piñeiro-Yañez E, Van de Poll F, et al. High burden of copy number alterations and c-MYC amplification in prostate cancer from BRCA2 germline mutation carriers. Ann Oncol. 2015;26(11):2293-300. https://doi.org/10.1093/annonc/mdv356

10. Castro E, Goh C, Leongamornlert D, Saunders E, Tymrakiewicz M, Dadaev T, et al. Effect of BRCA mutations on metastatic relapse and cause-specific survival after radical treatment for localised prostate cancer. Eur Urol. 2015;68(2):186-93. https://doi.org/10.1016/j.eururo.2014.10.022

11. Castro E, Goh C, Olmos D, Saunders E, Leongamornlert D, Tymrakiewicz M, et al. Germline BRCA mutations are associated with higher risk of nodal involvement, distant metastasis, and poor survival outcomes in prostate cancer. J Clin Oncol. 2013;31(14):1748-57. https://doi.org/10.1200/ JCO.2012.43.1882

12. Mateo J, Carreira S, Sandhu S, Miranda S, Mossop H, Perez-Lopez R, et al. DNA-repair defects and olaparib in metastatic prostate cancer. N Engl J Med. 2015;373(18):1697-708. https://doi. org/10.1056/NEJMoal506859

13. Mateo J, Porta N, Bianchini D, McGovern U, Elliott T, Jones R, et al. Olaparib in patients with metastatic castration-resistant prostate cancer with DNA repair gene aberrations (TOPARP-B): a multicentre, open-label, randomised, phase 2 trial. Lancet Oncol. 2020;21(1):162-74. https://doi. org/10.1016/S1470-2045(19)30684-9

14. Abida W, Bryce AH, Vogelzang NJ, Amatao R, Percent I, Shapiro J. Preliminary results from TRITON2: a phase 2 study of rucaparib in patients with metastatic castration-resistant prostate cancer (mCRPC) 
associated with homologous recombination repair (HRR) gene alterations. Ann Oncol. 2018;29 (suppl 8):vii271-vii302. https://doi.org/10.1093/annonc/mdy284.002

15. Smith M, Sandhu S, Kelly W, Scher H, Efstathiou E, Lara P, et al. Pre-specified interim analysis of GALAHAD: a phase II study of niraparib in patients (pts) with metastatic castration-resistant prostate cancer (mCRPC) and biallelic DNA-repair gene defects (DRD). Ann Oncol. 2019;30:v884-v5. https:// doi.org/10.1093/annonc/mdz394.043

16. Hussain M, Mateo J, Fizazi K, Saad F, Shore N, Sandhu S, et al. PROfound: Phase III study of olaparib versus enzalutamide or abiraterone for metastatic castration-resistant prostate cancer (mCRPC) with homologous recombination repair (HRR) gene alterations. Ann Oncol. 2019;30:v881-v2. https://doi. org/10.1093/annonc/mdz394.039

17. Hussain M, Mateo J, Fizazi K, Saad F, Shore N, Sandhu S, et al. Survival with olaparib in metastatic castration-resistant prostate cancer. N Engl J Med. 2020;383(24):2345-57. https://doi.org/10.1056/ NEJMoa2022485

18. de Bono J, Mateo J, Fizazi K, Saad F, Shore N, Sandhu S, et al. Olaparib for metastatic castration-resistant prostate cancer. N Engl J Med. 2020;382(22):2091-102. https://doi.org/10.1056/NEJMoa1911440

19. Markowski MC, Antonarakis ES. BRCA1 versus BRCA2 and PARP inhibitor sensitivity in prostate cancer: more different than alike? J Clin Oncol. 2020;38(32):3735-9. https://doi.org/10.1200/ JCO.20.02246

20. Vogelstein B, Lane D, Levine AJ. Surfing the p53 network. Nature. 2000;408(6810):307-10. https:// doi.org/10.1038/35042675

21. DeLeo AB, Jay G, Appella E, Dubois GC, Law LW, Old LJ. Detection of a transformation-related antigen in chemically induced sarcomas and other transformed cells of the mouse. Proc Natl Acad Sci U S A. 1979;76(5):2420-4. https://doi.org/10.1073/pnas.76.5.2420

22. Lane DP, Crawford LV. T antigen is bound to a host protein in SY40-transformed cells. Nature. 1979;278(5701):261-3. https://doi.org/10.1038/27826la0

23. Linzer DI, Levine AJ. Characterization of a $54 \mathrm{~K}$ dalton cellular SV40 tumor antigen present in SV40transformed cells and uninfected embryonal carcinoma cells. Cell. 1979;17(1):43-52. https://doi. org/10.1016/0092-8674(79)90293-9

24. Mercer WE, Avignolo C, Baserga R. Role of the p53 protein in cell proliferation as studied by microinjection of monoclonal antibodies. Mol Cell Biol. 1984;4(2):276-81. https://doi.org/10.1128/ MCB.4.2.276

25. Levine AJ. p53: 800 million years of evolution and 40 years of discovery. Nat Rev Cancer. 2020;20(8):471-80. https://doi.org/10.1038/s41568-020-0262-1

26. Lane DP. p53, guardian of the genome. Nature. 1992;358(6381):15-6. https://doi.org/10.1038 $1358015 \mathrm{a} 0$

27. Levine AJ, Momand J, Finlay CA. The p53 tumour suppressor gene. Nature. 1991;351(6326):453-6. https://doi.org/10.1038/351453a0

28. Oren M. p53: the ultimate tumor suppressor gene? Faseb J. 1992;6(13):3169-76. https://doi. org/10.1096/fasebj.6.13.1397838

29. Liu Y, Tavana O, Gu W. p53 modifications: exquisite decorations of the powerful guardian. J Mol Cell Biol. 2019;11(7):564-77. https://doi.org/10.1093/jmcb/mjz060

30. Oliner JD, Pietenpol JA, Thiagalingam S, Gyuris J, Kinzler KW, Vogelstein B. Oncoprotein MDM2 conceals the activation domain of tumour suppressor p53. Nature. 1993;362(6423):857-60. https:// doi.org/10.1038/362857a0

31. Durocher D, Jackson SP. DNA-PK, ATM and ATR as sensors of DNA damage: variations on a theme? Curr Opin Cell Biol. 2001;13(2):225-31. https://doi.org/10.1016/S0955-0674(00)00201-5

32. Weber JD, Taylor LJ, Roussel MF, Sherr CJ, Bar-Sagi D. Nucleolar Arf sequesters Mdm2 and activates p53. Nat Cell Biol. 1999;1(1):20-6. https://doi.org/10.1038/8991

33. Li M, Chen D, Shiloh A, Luo J, Nikolaev AY, Qin J, et al. Deubiquitination of p53 by HAUSP is an important pathway for p53 stabilization. Nature. 2002;416(6881):648-53. https://doi.org/10.1038/ nature 737

34. Marine JC, Francoz S, Maetens M, Wahl G, Toledo F, Lozano G. Keeping p53 in check: essential and synergistic functions of Mdm2 and Mdm4. Cell Death Differ. 2006;13(6):927-34. https://doi. org/10.1038/sj.cdd. 4401912 
35. Mertens F, Johansson B, Höglund M, Mitelman F. Chromosomal imbalance maps of malignant solid tumors: a cytogenetic survey of 3185 neoplasms. Cancer Res. 1997;57(13):2765-80.

36. el-Deiry WS, Kern SE, Pietenpol JA, Kinzler KW, Vogelstein B. Definition of a consensus binding site for p53. Nat Genet. 1992;1(1):45-9. https://doi.org/10.1038/ng0492-45

37. Donehower LA, Soussi T, Korkut A, Liu Y, Schultz A, Cardenas M, et al. Integrated analysis of TP53 gene and pathway alterations in the cancer genome atlas. Cell Rep. 2019;28(5):1370-84.e5. https:// doi.org/10.1016/j.celrep.2019.07.001

38. Rodrigues NR, Rowan A, Smith ME, Kerr IB, Bodmer WF, Gannon JV, et al. p53 mutations in colorectal cancer. Proc Natl Acad Sci U S A. 1990;87(19):7555-9. https://doi.org/10.1073/ pnas.87.19.7555

39. Baugh EH, Ke H, Levine AJ, Bonneau RA, Chan CS. Why are there hotspot mutations in the TP53 gene in human cancers? Cell Death Differ. 2018;25(1):154-60. https://doi.org/10.1038/cdd.2017.180

40. Olivier M, Hollstein M, Hainaut P. TP53 mutations in human cancers: origins, consequences, and clinical use. Cold Spring Harb Perspect Biol. 2010;2(1):a001008-a. https://doi.org/10.1101/cshperspect.a001008

41. de Vries A, Flores ER, Miranda B, Hsieh HM, van Oostrom CT, Sage J, et al. Targeted point mutations of p53 lead to dominant-negative inhibition of wild-type p53 function. Proc Natl Acad Sci U S A. 2002;99(5):2948-53. https://doi.org/10.1073/pnas.052713099

42. Oren M, Rotter V. Mutant p53 gain-of-function in cancer. Cold Spring Harb Perspect Biol. 2010;2(2):a001107. https://doi.org/10.1101/cshperspect.a001107

43. Li FP, Fraumeni JF, Jr. Soft-tissue sarcomas, breast cancer, and other neoplasms. A familial syndrome? Ann Intern Med. 1969;71(4):747-52. https://doi.org/10.7326/0003-4819-71-4-747

44. Birch JM, Alston RD, McNally RJQ, Evans DGR, Kelsey AM, Harris M, et al. Relative frequency and morphology of cancers in carriers of germline TP53 mutations. Oncogene. 2001;20(34):4621-8. https://doi.org/10.1038/sj.onc.1204621

45. Malkin D. Li-Fraumeni syndrome. Genes Cancer. 2011;2(4):475-84. https://doi.org/10.1177/ 1947601911413466

46. Navone NM, Troncoso P, Pisters LL, Goodrow TL, Palmer JL, Nichols WW, et al. p53 protein accumulation and gene mutation in the progression of human prostate carcinoma. J Natl Cancer Inst. 1993;85(20):1657-69. https://doi.org/10.1093/jnci/85.20.1657

47. Heidenberg HB, Sesterhenn IA, Gaddipati JP, Weghorst CM, Buzard GS, Moul JW, et al. Alteration of the tumor suppressor gene p53 in a high fraction of hormone refractory prostate cancer. J Urol. 1995;154(2 Pt 1):414-21. https://doi.org/10.1016/S0022-5347(01)67065-4

48. Hall MC, Navone NM, Troncoso P, Pollack A, Zagars GK, von Eschenbach AC, et al. Frequency and characterization of p53 mutations in clinically localized prostate cancer. Urology. 1995;45(3):470-5. https://doi.org/10.1016/S0090-4295(99)80018-1

49. Bookstein R, MacGrogan D, Hilsenbeck SG, Sharkey F, Allred DC. p53 is mutated in a subset of advanced-stage prostate cancers. Cancer Res. 1993;53(14):3369-73.

50. Nientiedt C, Endris V, Jenzer M, Mansour J, Sedehi NTP, Pecqueux C, et al. High prevalence of DNA damage repair gene defects and TP53 alterations in men with treatment-naïve metastatic prostate cancer-results from a prospective pilot study using a 37 gene panel. Urol Oncol. 2020;38(7):637. e17-.e27. https://doi.org/10.1016/j.urolonc.2020.03.001

51. Abeshouse A, Ahn J, Akbani R, Ally A, Amin S, Andry Christopher D, et al. The molecular taxonomy of primary prostate cancer. Cell. 2015;163(4):1011-25. https://doi.org/10.1016/j. cell.2015.10.025

52. Mateo J, Seed G, Bertan C, Rescigno P, Dolling D, Figueiredo I, et al. Genomics of lethal prostate cancer at diagnosis and castration resistance. J Clin Invest. 2020;130(4):1743-51. https://doi.org/10.1172/ JCI132031

53. Hamid AA, Gray KP, Shaw G, MacConaill LE, Evan C, Bernard B, et al. Compound genomic alterations of TP53, PTEN, and RB1 tumor suppressors in localized and metastatic prostate cancer. Eur Urol. 2019;76(1):89-97. https://doi.org/10.1016/j.eururo.2018.11.045

54. Liu W, Xie CC, Thomas CY, Kim S-T, Lindberg J, Egevad L, et al. Genetic markers associated with early cancer-specific mortality following prostatectomy. Cancer. 2013;119(13):2405-12. https://doi. org/10.1002/cncr.27954 
55. Fraser M, Sabelnykova VY, Yamaguchi TN, Heisler LE, Livingstone J, Huang V, et al. Genomic hallmarks of localized, non-indolent prostate cancer. Nature. 2017;541(7637):359-64. https://doi. org/10.1038/nature20788

56. Armenia J, Wankowicz SAM, Liu D, Gao J, Kundra R, Reznik E, et al. The long tail of oncogenic drivers in prostate cancer. Nat Genet. 2018;50(5):645-51. https://doi.org/10.1038/s41588-018-0078-z

57. Barbieri CE, Baca SC, Lawrence MS, Demichelis F, Blattner M, Theurillat J-P, et al. Exome sequencing identifies recurrent SPOP, FOXAl and MED12 mutations in prostate cancer. Nat Genet. 2012;44(6):685-9. https://doi.org/10.1038/ng.2279

58. Abida W, Armenia J, Gopalan A, Brennan R, Walsh M, Barron D, et al. Prospective genomic profiling of prostate cancer across disease states reveals germline and somatic alterations that may affect clinical decision making. JCO Precis Oncol. 2017;2017:PO.17.00029.

59. Robinson D, Van Allen EM, Wu YM, Schultz N, Lonigro RJ, Mosquera JM, et al. Integrative clinical genomics of advanced prostate cancer. Cell. 2015;161(5):1215-28. https://doi.org/10.1016/j. cell.2015.05.001

60. Beltran H, Yelensky R, Frampton GM, Park K, Downing SR, MacDonald TY, et al. Targeted nextgeneration sequencing of advanced prostate cancer identifies potential therapeutic targets and disease heterogeneity. Eur Urol. 2013;63(5):920-6. https://doi.org/10.1016/j.eururo.2012.08.053

61. Kumar A, White TA, MacKenzie AP, Clegg N, Lee C, Dumpit RF, et al. Exome sequencing identifies a spectrum of mutation frequencies in advanced and lethal prostate cancers. Proc Natl Acad Sci U S A. 2011;108(41):17087-92. https://doi.org/10.1073/pnas.1108745108

62. Nyquist MD, Corella A, Coleman I, De Sarkar N, Kaipainen A, Ha G, et al. Combined TP53 and RB1 loss promotes prostate cancer resistance to a spectrum of therapeutics and confers vulnerability to replication stress. Cell Rep. 2020;31(8):107669. https://doi.org/10.1016/j.celrep.2020.107669

63. van Dessel LF, van Riet J, Smits M, Zhu Y, Hamberg P, van der Heijden MS, et al. The genomic landscape of metastatic castration-resistant prostate cancers reveals multiple distinct genotypes with potential clinical impact. Nat Commun. 2019;10(1):5251. https://doi.org/10.1038/s41467-019-13084-7

64. Sartor O, de Bono JS. Metastatic prostate cancer. N Engl J Med. 2018;378(7):645-57. https://doi. org/10.1056/NEJMral701695

65. Attard G, de Bono JS. Translating scientific advancement into clinical benefit for castration-resistant prostate cancer patients. Clin Cancer Res. 2011;17(12):3867-75. https://doi.org/10.1158/10780432.CCR-11-0943

66. de Bono JS, Logothetis CJ, Molina A, Fizazi K, North S, Chu L, et al. Abiraterone and increased survival in metastatic prostate cancer. N Engl J Med. 2011;364(21):1995-2005. https://doi.org/10.1056/ NEJMoal014618

67. Scher HI, Fizazi K, Saad F, Taplin ME, Sternberg CN, Miller K, et al. Increased survival with enzalutamide in prostate cancer after chemotherapy. N Engl J Med. 2012;367(13):1187-97. https://doi. org/10.1056/NEJMoa1207506

68. Attard G, Parker C, Eeles RA, Schröder F, Tomlins SA, Tannock I, et al. Prostate cancer. Lancet. 2016;387(10013):70-82. https://doi.org/10.1016/S0140-6736(14)61947-4

69. Antonarakis ES, Lu C, Wang H, Luber B, Nakazawa M, Roeser JC, et al. AR-V7 and resistance to enzalutamide and abiraterone in prostate cancer. N Engl J Med. 2014;371(11):1028-38. https://doi. org/10.1056/NEJMoal315815

70. Bernemann C, Schnoeller TJ, Luedeke M, Steinestel K, Boegemann M, Schrader AJ, et al. Expression of AR-V7 in circulating tumour cells does not preclude response to next generation androgen deprivation therapy in patients with castration resistant prostate cancer. Eur Urol. 2017;71(1):1-3. https:// doi.org/10.1016/j.eururo.2016.07.021

71. De Laere B, Oeyen S, Mayrhofer M, Whitington T, van Dam PJ, Van Oyen P, et al. TP53 outperforms other androgen receptor biomarkers to predict abiraterone or enzalutamide outcome in metastatic castration-resistant prostate cancer. Clin Cancer Res. 2019;25(6):1766-73. https://doi. org/10.1158/1078-0432.CCR-18-1943

72. Shenk JL, Fisher CJ, Chen SY, Zhou XF, Tillman K, Shemshedini L. p53 represses androgen-induced transactivation of prostate-specific antigen by disrupting hAR amino- to carboxyl-terminal interaction. J Biol Chem. 2001;276(42):38472-9. https://doi.org/10.1074/jbc.M103652200 
73. Gurova KV, Roklin OW, Krivokrysenko VI, Chumakov PM, Cohen MB, Feinstein E, et al. Expression of prostate specific antigen (PSA) is negatively regulated by p53. Oncogene. 2002;21(1):153-7. https://doi.org/10.1038/sj.onc. 1205001

74. Cronauer MV, Schulz WA, Burchardt T, Ackermann R, Burchardt M. Inhibition of p53 function diminishes androgen receptor-mediated signaling in prostate cancer cell lines. Oncogene. 2004;23(20):3541-9. https://doi.org/10.1038/sj.onc.1207346

75. Tannock IF, de Wit R, Berry WR, Horti J, Pluzanska A, Chi KN, et al. Docetaxel plus prednisone or mitoxantrone plus prednisone for advanced prostate cancer. N Engl J Med. 2004;351(15):1502-12. https://doi.org/10.1056/NEJMoa040720

76. Petrylak DP. The treatment of hormone-refractory prostate cancer: docetaxel and beyond. Rev Urol. 2006;8(Suppl 2):S48-S55.

77. Liu C, Zhu Y, Lou W, Nadiminty N, Chen X, Zhou Q, et al. Functional p53 determines docetaxel sensitivity in prostate cancer cells. Prostate. 2013;73(4):418-27. https://doi.org/10.1002/pros.22583

78. Gundem G, Van Loo P, Kremeyer B, Alexandrov LB, Tubio JMC, Papaemmanuil E, et al. The evolutionary history of lethal metastatic prostate cancer. Nature. 2015;520(7547):353-7. https://doi. org/10.1038/nature14347

79. Haffner MC, Mosbruger T, Esopi DM, Fedor H, Heaphy CM, Walker DA, et al. Tracking the clonal origin of lethal prostate cancer. J Clin Invest. 2013;123(11):4918-22. https://doi.org/10.1172/JCI70354

80. Hong MK, Macintyre G, Wedge DC, Van Loo P, Patel K, Lunke S, et al. Tracking the origins and drivers of subclonal metastatic expansion in prostate cancer. Nat Commun. 2015;6:6605. https://doi. org/10.1038/ncomms7605

81. Eastham JA, Hall SJ, Sehgal I, Wang J, Timme TL, Yang G, et al. In vivo gene therapy with p53 or p21 adenovirus for prostate cancer. Cancer Res. 1995;55(22):5151-5.

82. Chappell WH, Lehmann BD, Terrian DM, Abrams SL, Steelman LS, McCubrey JA. p53 expression controls prostate cancer sensitivity to chemotherapy and the MDM2 inhibitor Nutlin-3. Cell Cycle. 2012;11(24):4579-88. https://doi.org/10.4161/cc.22852

83. Duffy MJ, Synnott NC, McGowan PM, Crown J, O'Connor D, Gallagher WM. p53 as a target for the treatment of cancer. Cancer Treat Rev. 2014;40(10):1153-60. https://doi.org/10.1016/j.ctrv. 2014.10.004

84. Hong B, van den Heuvel AP, Prabhu VV, Zhang S, El-Deiry WS. Targeting tumor suppressor p53 for cancer therapy: strategies, challenges and opportunities. Curr Drug Targets. 2014;15(1):80-9. https:// doi.org/10.2174/1389450114666140106101412

85. Sabapathy K, Lane DP. Therapeutic targeting of p53: all mutants are equal, but some mutants are more equal than others. Nat Rev Clin Oncol. 2018;15(1):13-30. https://doi.org/10.1038/ nrclinonc.2017.151

86. DeLeo AB, Appella E. The p53 saga: early steps in the development of tumor immunotherapy. J Immunol. 2020;204(9):2321-8. https://doi.org/10.4049/jimmunol.1901343 
